\title{
IMPROVING THE PERFORMANCE OF PRIMARY HEALTHCARE CENTERS IN SURABAYA: A COMPARISON OF LEADERSHIP STYLE AND VERTICAL DYAD LINKAGE
}

\author{
Upaya Peningkatan Kinerja Puskesmas di Kota Surabaya: Perbandingan Gaya \\ Kepemimpinan versus Vertical Dyad Linkage \\ *Danoe Soesanto \\ IAKMI Jawa Timur, Indonesia \\ *Correspondence: danoe.soesanto-13@fkm.unair.ac.id
}

\begin{abstract}
Background: Leadership style and Vertical Dyad Linkage have a significant influence on organization's performance, especially public health service providers. Leadership style is one factor that will influence the performance and management of primary healthcare center (PHC).

Aim: This study aims to investigate the influence of leadership style and leader-member exchange to the performance of PHC.

Methods: The research is an observational study with a cross-sectional design. There were $27 \mathrm{PHCs}$ involved in the study. Each PHC was represented by 11 respondents including the directors, five health program coordinators, and their five members. Data were collected with questionnaires and then analyzed using Multinomial Logistic Regression $(\alpha=0.05)$.

Results: The results of the research show that (37.05\%) of PHCs use supportive leadership style, and (33.33\%) of them use participative leadership style. Most of the Vertical Dyad Linkage of PHC were imbalanced social overinvestment (40.7\%), and the work performance showed enough performance (59.3\%). Path-Goal leadership had the most influence on the performance of PHC.

Conclusions: Excellent performance of $\mathrm{PHC}$ is related to achievement-oriented leadership style. Work performance of PHC can be improved by improving real neutral leader-member exchange. Furthermore, identifying employees' maturity can be chosen as the leadership style. Employees' self-esteem can be developed to improve the work performance of $\mathrm{PHC}$.
\end{abstract}

Keywords: Leadership style, Vertical Dyad Linkage, Performance of primary healthcare centre.

\begin{abstract}
ABSTRAK
Latar Belakang: Gaya kepemimpinan dan Vertical Dyad Linkage sangat berpengaruh terhadap kinerja organisasi terutama pada penyedia pelayanan kesehatan. Gaya kepemimpinan merupakan salah satu faktor yang akan mempengaruhi kinerja dan managemen pusat pelayanan kesehatan (puskesmas).

Tujuan: Penelitian ini bertujuan untuk mengetahui pengaruh gaya kepemimpinan dan dan pertukaran hubungan antara pemimpin dengan karyawan terhadap kinerja puskesmas Kota Surabaya.

Metode: Penelitian ini merupakan penelitian observasional dengan rancangan cross sectional. Terdapat 27 puskesmas yang terlibat dalam penelitian ini, setiap puskesmas diwakili oleh 11 responden terdiri dari Kepala Puskesmas, 5 staf non struktural dan 5 staf struktural. Data didapatkan dengan instrumen kuesioner kemudian dianalisis dengan Multinomial Logistic Regression ( $\alpha=0,05)$.

Hasil: Hasil penelitian menunjukkan di puskesmas Kota Surabaya mayoritas (37,05\%) Kepala Puskesmas menerapkan gaya kepemimpinan suportif dan gaya kepemimpinan partisipasi (33,33\%). Vertikal Dyad Linkage sebagian besar adalah imbalanced social overinvestment (40,75\%) dan kinerja aspek manajemen puskesmas menunjukkan kinerja cukup (59,3\%). Gaya kepemimpinan berdasarkan Path-Goal merupakan gaya kepemimpinan yang paling berpengaruh terhadap kinerja puskesmas.

Kesimpulan: Kinerja puskesmas yang baik terkait dengan gaya kepemimpinan berorientasi pada pencapaian. Kinerja puskesmas dapat ditingkatkan dengan meningkatkan kualitas petukaran hubungan menjadi positif netral. Pemimpin harus dapat mengidentifikasi tingkat maturitas karyawan sehingga dapat memilih gaya kepemimpinan yang sesuai dan proaktif meningkatkan rasa percaya diri karyawan sehingga kinerja puskesmas aspek manajemen dapat ditingkatkan.
\end{abstract}

Kata Kunci: Gaya kepemimpinan, Vertical Dyad Linkage, Kinerja puskesmas. 


\section{INTRODUCTION}

Primary healthcare center (PHC) or puskesmas plays a vital role in achieving national health development goals. As the industrial implementing unit of the regional healthcare, $\mathrm{PHC}$ carries out public health efforts and first-rate individual health efforts, which prioritize persuasive and preventive health efforts to achieve the highest level of public health in its work area (Ministry of Health of the Republic Indonesia, 2014).

The benchmark for the success of state administrators can be seen from the quality of public services, such as the PHC. The performance assessment of PHC or Penilaian Kinerja Puskesmas (PKP) is an effort to evaluate the work performance of PHCs. PKP is essential as an effort to improve the performance of PHC in both health services and management aspects. The scope of assessment of the performance of PHC includes an assessment on the achievement of the implementation of health services, the management of PHC, and the quality of services (East Java Province Health Office, 2012).

Organizational performance in a functional category is the result of group work that can produce goods or services of high quality using a minimum amount of resources. Productivity and quality improvement take place on an ongoing basis of achieving the mission of the organization (Popovich, 1998). The success of an organization's performance can be influenced by the factors of leadership style and the relationship between leaders and employees (Vertical Dyad Linkage) (Greenberg, 2003). Leadership style is defined as the behavior or method chosen and used by the leaders in influencing thoughts, feelings, attitudes, and behavior of the organization (Nawawi, 2005).

There are four leadership styles based on Path-Goal, namely directive, supportive, participatory and achievement-oriented. Path-Goal leadership style emphasizes the way leaders lead in facilitating employee's performance. The Path-Goal Theory also states that job satisfaction and performance depend on employee's expectations, and they are influenced by the employee and environmental characteristics faced by employees. Based on previous research, it is known that leadership style influences organizational performance.

Hersey and Blanchard's situational leadership style emphasizes the selection of the right leadership style to deal with certain situations and the maturity level of employees (Thoha, 2003). The relationship between leaders and employees is the exchange of interpersonal relationships between the two. Vertical Dyad Linkage consists of three components, namely the leader, who is the boss; the employee, who is the subordinate; and the change, which illustrates interactions between leaders and employees, and sharing suggestions on the amount of intensity and quality of communication between the two parties (Sparrowe and Liden, 1997)

In terms of management, PHCs in Surabaya have shown excellent performance. In the contrary, when viewed from performance trend, many
$(43.75 \%)$ still have problematic performance trends in terms of management (East Java Province Health Office, 2012). The purpose of this study is to determine the effect of leadership style, employee maturity level, and leader-employee relationship (Vertical Dyad Linkage) on the performance of PHC, especially in terms of management.

\section{METHOD}

The research was an analytic research with observational approach. Research variables were measured cross-sectionally so that a picture of the situation at that time can be obtained. The population of this study was 62 health centers in Surabaya. Twenty-seven health centers had fulfilled the inclusion criteria, including having a complete performance appraisal report from 2011 to 2013, and at least three-year work period for the directors.

The sample in this study was taken randomly from PHCs that were represented by 11 respondents: one director, five health program coordinators, and five members of the program. The leadership style variable was identified using PathGoal Leadership Questionnaire (Indvik, 1988). This questionnaire contains 20 questions consisting of directives style in questions no: $1,5,9,14$, and 18 . Supportive style is represented by questions no: 2 , $8,11,15$, and 20. Participative style are explained in questions no: $3,4,7,12$, and 17 . Achievementoriented style of leadership style is found in questions no: $6,10,13,16$, and 19 (Indvik, 1988).

The next variable is leadership style. In this research, leadership style of PHC directors is assessed by employees using Hersey and Blanchard's Leadership Effectiveness and Adaptability Description research instruments (LEAD-Others) (Hersey and Blanchard, 2004). Once the results of the respondents' answers were obtained, data analysis techniques were carried out by moving the respondents' answers to a table which later be used to interpret the leadership style.

Level of employee's maturity was measured with a questionnaire about employee's maturity level or Readiness Scale Staff Member (RSSM) (Yoshioka, 2006). The questionnaire contains 12 questions with multiple rating list scale. Respondents were asked to choose numbers from one to eight according to their ability and willingness to complete the task. The combination of ability and willingness shows employee maturity. R1 shows that employees have a low level of maturity (inability and low willingness). R2 shows a moderate level of maturity (employees are unable, but willing to assume responsibility). R3 shows a high level of maturity (high employee ability, but a low willingness to assume responsibility), and R4 shows a very high level of maturity (employees have high ability and willingness to assume responsibility). These are described in the table of Employee Matrix from the Center for Leadership Studies, Inc. (Yoshioka, 2006).

Vertical Dyad Linkage variables were measured using Exchange LMX-MDM's Multidimensional Leader-Member from Liden and Maslyn (1998). The Quality of Leader-Member Exchange (LMX) in this study was measured by 
mapping the value of Leader-Member Exchange from the perspective of the leaders and employees described in the relationship diagram of the LeaderMember Exchange. The measurement results of the Leader-Member Exchange are in the form of quality categories from the Leader-Member Exchange between the PHC directors and their employees. Some of the quality relationship are grouped into the lowest to the highest relationship quality (negative balanced, negative neutral, and imbalanced formal overinvestment, imbalanced social overinvestment, positive neutral and positive balanced).

The results of the measurement on the quality of the exchange of relations between PHC directors and their employees were then interpreted into a graph. The $x$-axis is the leader-member exchange assessment conducted by the leader. The $y$-axis is the assessment of leader-member exchange conducted by employees. The range of $x-$ axis and $y$-axis values is the value given by employees after executing and answering the LMXMDM questionnaire. There are five different areas in this graph. These areas represent the categories of leader-member exchange formed between leaders and employees (Putri and Nurul R, 2012).

Unit performance variables were measured from the average achievement of the performance of PHCs based on the PKP report. The influence of variables is proven using multinomial logistic regression test. The average performance trend of $\mathrm{PHC}$ in terms of management aspect was obtained from secondary data, such as guidelines for assesing performance of $\mathrm{PHC}$ or Pedoman Penilaian Kinerja Puskesmas (P2KP) for 27 health centers in Surabaya from 2011 to 2013. All research instruments have fulfilled validity and reliability requirements.

Data analysis was carried out for each research variable. Data processing was done in the following stages: editing, coding, processing, and cleaning (Hastono, 2016).

After the data were obtained, they were analyzed and interpreted to examine the hypothesis. The first analysis is the univariable analysis to determine the distribution and proportion of the independent variables and dependent variable. The independent variables in this study consisted of Path-Goal leadership style variables including directive, supportive, participatory, and achievement-oriented, combination leadership style, and no dominant leadership style. Vertical Dyad Linkage variables include the dimensions of effect, professional respect, contribution, and loyalty.

The dependent variable in this study was measured by identifying the performance of $\mathrm{PHC}$ retrospectively consisting of poor, sufficient, and good performance categories. The data obtained were collected and presented in a table. Results of the analysis were then categorized based on the number of composite values, and calculated based on the mean value and Standard Deviation (SD). Data calculation is categorized into several classifications according to the operational definitions.

The next analysis was bivariable analysis to assess the relationship between independent and dependent variables. Bivariable analysis was done to see the relationship between two variables, namely Path-Goal leadership style variables, "Hersey and Blanchard" leadership style, employee's maturity level, and Vertical Dyad Linkage with the performance of PHC. The method used was cross tabulation between the independent variables and the dependent variable. Multinomial regression test was carried out to determine the effect of independent variables including Path-Goal leadership style variables on the dependent variable.

The cross tabulation involved the following: Path-Goal leadership style towards Vertical Dyad Linkage, Path-Goal leadership style towards employee maturity level, "Hersey and Blanchard" leadership style to the dependent variable, employee's maturity level, and Vertical Dyad Linkage, employee maturity level to a dependent variable the performance of PHC in Surabaya. Vertical Dyad Linkage on the performance of PHC, Vertical Dyad Linkage on employee's maturity level is dependent variable on the performance of $\mathrm{PHC}$ in Surabaya.

\section{RESULTS AND DISCUSSION}

\section{Characteristics of PHC Directors in Surabaya}

The leadership style of PHC directors is always related to the leaders' characteristics, such as age, gender, level of education, and length of time serving as $\mathrm{PHC}$ director. The majority of the directors are $\geq 50$ years old $(74.07 \%)$. Those who are $\geq 50$ years have had much experience in leading an organization and are often identified to have wise nature. Wisdom is defined as a part of fluid intelligent (Kimmel, 1990). Wisdom is the ability to make a proper assessment of essential but uncertain things in leading an organization. Younger leaders tend to be dynamic and idealistic. Most of $\mathrm{PHC}$ directors in Surabaya are doctors (66.66\%). The level of education is one of factors that can shape the character of human life. Most of PHC directors in Surabaya have served as a director for more than 18 years $(48.15 \%)$. The long process of serving as a leader tends to shape one's maturity and learn a lot about mistakes and try to improve them. Most of the directors were women (74.07\%). Female leaders are more subjected to tenderness, motherhood, and affective feelings.

\section{Performance of PHC in Terms of Management Aspects}

Performance assessment of PHC in terms of management aspects consists of these variables: operational management, management of tools and drugs, financial management, management of labor, financing management, and asset management (East Java Province Health Office, 2012). Data processing activities include activities to examine the completeness and correctness of data, calculation to get the value of the situation, and performance achievement of $\mathrm{PHC}$, as well as data tabulations for decision making.

Data processing method was done by calculating the performance of $\mathrm{PHC}$. There are 3 
components of assessment of the main activities and variables that need to be processed, namely: the implementation component, the management component, and the quality component (East Java Province Health Office, 2012). This study only focuses on the assessment of the performance of $\mathrm{PHC}$ in terms of management aspect.

The results show that the performances of PHCs in Surabaya in 2011 were as follows: inadequate performance $(14.80 \%)$, adequate performance (33.30\%), and good performance (51.90\%). Most of PHCs in Surabaya in 2012 had adequate performance $(33.30 \%)$ and good performance $(66.70 \%)$. In 2013 , most of them had adequate performance $(33.30 \%)$ and good performance $(66.70 \%)$. In 2014 , data showed inadequate performance $(7.40 \%)$, adequate performance $(59.30 \%)$ and good performance (33.30\%) from 2011 to 2013.

\section{Leadership Style of PHC Directors in Surabaya}

Leadership style is an essential factor in an organization because it will determine the way a leader influences and directs employees to achieve organizational goals. The influence of leadership style applied by PHC directors is based on the PathGoal approach which consists of directive, supportive, participative, and achievement-oriented leadership style.

Based on the Path-Goal theory, it is said that leaders must have flexibility in applying leadership styles that are appropriate to a particular situation
(Erwati, 2009). Leaders cannot be separated from the attitude shown by their employees in carrying out their duties to achieve goals. Effective leadership must provide direction to achieve organizational goals (Decoster and Fertakis, 1968)

Supportive leadership style was widely applied (37.05\%) by PHC directors in Surabaya. PHC directors with supportive leadership style are concerned with the needs of employees and treat all employees equally. They recognize the existence, status, and personal needs of employees. They affect employees' performance which will ultimately affect organizational performance.

Some PHC directors also applied a combination of participative leadership and achievement-oriented styles to improve employees' performance. These leaders show a concern towards employees' suggestions and ideas. They give challenging goals, expect employees to perform as good as possible, and continuously seek more achievements of goals. The application of participative leadership style and achievementoriented leadership style can later provide outcomes for good individual performance and ultimately will have an impact on good organizational performance. According to Reardon (Reardon, 1998), leaders with supportive leadership styles learn more by observing work results and employees' reactions towards leader's decisions. The influence of Path-goal leadership style towards the performance of PHC can be seen in Table 1.

Table 1. Cross Tabulation between Path-Goal Leadership Style and Performance of PHC from Management Aspects in 2015.

\begin{tabular}{lcccccccc}
\hline \multirow{2}{*}{$\begin{array}{c}\text { Path-Goal Leadership } \\
\text { Style }\end{array}$} & \multicolumn{4}{c}{ Performance of Primary Healthcare Centre } & & \multirow{2}{*}{ Total } \\
\cline { 2 - 9 } & \multicolumn{2}{c}{ Inadequate } & \multicolumn{2}{c}{ Adequate } & \multicolumn{2}{c}{ Good } & & \\
\cline { 2 - 8 } & $\mathbf{n}$ & $\%$ & $\mathbf{n}$ & $\%$ & $\mathbf{n}$ & $\%$ & $\mathbf{n}$ & $\%$ \\
\hline Supportive & 2 & 20.00 & 8 & 80.00 & 0 & 0.00 & 10 & 100.00 \\
\hline Participative & 0 & 0.00 & 8 & 88.90 & 1 & 11.10 & 9 & 100.00 \\
\hline Achievement Oriented & 0 & 0.00 & 0 & 0.00 & 6 & 100.00 & 6 & 100.00 \\
\hline Combinative & 0 & 0.00 & 0 & 0.00 & 2 & 100.00 & 2 & 100.00 \\
\hline Total & 2 & 7.40 & 16 & 59.26 & 9 & 33.34 & 27 & 100.00 \\
\hline
\end{tabular}

Table 1 shows that the application of supportive leadership style and participative leadership style has more impact on satisfactory performance. The application of achievementoriented leadership style will have an impact on good performance. The adoption of a participative leadership style and achievement-oriented leadership style will have more impact on good performance. Leadership styles based on Path-Goal is more appropriately applied in PHCs in Surabaya because these leadership styles will facilitate employees in completing the work to achieve organizational goals. Path-Goal leadership style is more in line with the personality traits of employees in PHCs.

Path-Goal leadership style affects the performance of PHCs in terms of management aspect. Results show that Path-Goal leadership styles significantly influences $(p=0.001(p$ $<0.005)$ )the performance of PHC amounted to $82.30 \%$ in terms of management aspect, while the rest $(17.70 \%)$ is influenced by other variables which were not examined. The results of this study are in line with Path-Goal (Robin and Judge, 2009) which explains that leaders will try to influence the perception of employees by motivating, providing clear description of task, achieving goals and job satisfaction, as well as implementing practical work. The application of the achievement-oriented leadership style is supposed to give PHCs good management performance (Iskandar, Ahmad, and Martua, 2013).

Supportive leadership style significantly influences the performance of PHCs in terms of management aspect (6.67 times greater than the directive, participatory, and achievement-oriented leadership styles). The supportive leadership style applied by PHC directors pays attention to the needs of employees, treats all employees equally, and recognizes the existence, status, and personal needs that affect employees' performance which will ultimately affect organizational performance (Soesanto, 2016). 
The leadership style of PHC directors in Surabaya is the situational leadership style of "Hersey and Blanchard". Results reveal that most of the leadership styles in PHCs in Surabaya were participative leadership style (37.10\%). Participative leadership style is suitable to be applied for subordinates with good abilities but low willingness to carry out a given task.

Leadership style based on "Hersey and Blanchard" also affects the performance of PHCs. The selling leadership style has an impact on adequate performance (85.70\%), and the delegating leadership style results in a good category (77. $80 \%$ ). Results of the study indicate that if $\mathrm{PHC}$ directors apply a delegating leadership style or a combination of styles (participating and delegating), it will result in good performance. The assessment on "Hersey and Blanchard" leadership style was carried out using Multinomial Regression test. Results show that "Hersey and Blanchard" leadership style significantly influence the performance of $\mathrm{PHCs}$ in terms of management aspect $(61.00 \%)$ and other factors which have not been studied (39.00\%).

The participative leadership style has a significant influence on the performance of PHCs in terms of management aspect. It is 28.5 times greater than telling, selling, and delegating style; though none is dominant. It can be concluded that leadership style based on Path-Goal has more influence in terms of management aspect compared to situational leadership style based on "Hersey and Blanchard."

\section{Employee's Maturity Level}

The level of employee's maturity is defined as the ability and willingness of followers to assume responsibility and direct their behavior. Based on the results, it can be seen that most of the employee's maturity levels in the PHCs in Surabaya in 2015 was high $(51.90 \%)$. It has been found that the level of employee's maturity affects the performance of PHCs in terms of management aspect. Medium employee's maturity level (20\%) and high employee's maturity level $(71.40 \%)$ result in adequate performance, while the high employee's maturity result in good performance $(75 \%)$. This means that the higher the employee's maturity is, the better the management aspect will be.

Employee's maturity level also influences the Path-Goal leadership style. Results show that employee maturity levels, which include M1, M2, $M 3$, and $M 4$, significantly influence the Path-Goal leadership style (41.5\%). Other factors that were not examined $(58.5 \%)$ can influence the Path-Goal leadership style. Employee's maturity level significantly influences the supportive leadership style 21.9 times higher than participatory leadership style and achievement-oriented leadership style.

Table 2. Cross Tabulation of Employee's Maturity Level with Path-Goal Leadership Style.

\begin{tabular}{|c|c|c|c|c|c|c|c|c|c|c|}
\hline \multirow{3}{*}{$\begin{array}{l}\text { Employee's } \\
\text { Maturity Level }\end{array}$} & \multicolumn{10}{|c|}{ Path-Goal Leadership Style } \\
\hline & \multicolumn{2}{|c|}{ Supportive } & \multicolumn{2}{|c|}{ Participative } & \multicolumn{2}{|c|}{ Achievement-Oriented } & \multicolumn{2}{|c|}{ Combinative } & \multicolumn{2}{|c|}{ Total } \\
\hline & $\mathbf{n}$ & $\%$ & $\mathbf{N}$ & $\%$ & $\mathbf{n}$ & $\%$ & $\mathbf{n}$ & $\%$ & $\mathbf{n}$ & $\%$ \\
\hline M2 & 4 & 80.00 & 1 & 20.00 & 0 & 0.00 & 0 & 0.00 & 5 & 100.0 \\
\hline M3 & 4 & 28.60 & 7 & 50.00 & 3 & 21.40 & 0 & 0.00 & 14 & 100.0 \\
\hline M4 & 1 & 12.50 & 2 & 25.00 & 3 & 37.50 & 2 & 25.00 & 8 & 100.0 \\
\hline
\end{tabular}

The high employee's maturity level has a more significant influence on participative leadership style. It was 10.8 times greater than supportive leadership style and achievement-oriented styles. Very high employee's maturity levels significantly influence achievement-oriented leadership style amounting 5.5 times higher than supportive leadership style and participatory leadership style. The influence of employee maturity on Path-Goal leadership style can be seen in Table 2 .

Based on Table 2, the employee's maturity level is related to supportive leadership style (80.00\%). High employee's motivation level is associated with participative leadership style $(50.00 \%)$, and very high employee maturity level is related more to achievement-oriented leadership style (37.50\%). The findings indicate that employees who have a moderate level of maturity are more in line with supportive leadership style. At a very high level, employee's maturity (able and willing) is more appropriate if a leader establishes achievementoriented leadership style to achieve the best performance.

In the Multinomial Regression test, the results show that the employee's maturity levels include leadership styles M1, M2, M3 M4. Combination Maturity Levels have a significant effect on the managerial performance amounted to $42.60 \%$ while the remaining $58.40 \%$ is influenced by other factors that were not examined. Medium employee's maturity has a significant effect 7.01 times greater than the high level and very high employee's maturity. High employee's maturity has a significant effect that result in adequate performance 7.32 times greater than the medium maturity level (M2) and very high maturity level (M4).

The level of employee's maturity also influences the "Hersey and Blanchard" leadership style. The employee's maturity has more impact on selling leadership style $(60.00 \%)$. Higher employee's maturity has more impact on participative leadership style $(42.90 \%)$. The high employee's maturity has more impact on the delegating leadership style $(50.00 \%)$. The results of the study show that selling leadership style would be more appropriately applied to employees with moderate maturity levels while very high employee's maturity would be more in line with the delegating leadership style.

The maturity level according to "Hersey and Blanchard" leadership style is categorized as M1, M2, M3, and M4. The combination of maturity levels significantly influenced the "Hersey and Blanchard" 
leadership style of $58.2 \%$. Another factor that was not examined $(41.8 \%)$ can influence "Hersey and Blanchard" leadership style. The results of the partial effect test show that maturity level is influential towards selling leadership style amounted to 9.8 times greater than participating, delegating and combination leadership styles. High employee maturity level was 19.8 times greater than the selling, delegating leadership style, and combination. Very high employee maturity levels significantly influence the delegating leadership style by 6.8 times higher than selling, participating and combination leadership styles. The leadership style applied by a leader would ideally be adjusted to the level of employee's maturity.

\section{Vertical Dyad Linkage in PHC of Surabaya}

Vertical Dyad Linkage Theory (VDL) focuses on reciprocal processes in the dyad (two parts in the form of interacting unity) and refers to the relationship between a leader and an employee only (Yukl, 1998). LMX not only looks at the attitude and behavior of leaders and employees, but emphasizes the quality of the relationships. The exchange of the relationship between the directors and employees was almost imbalanced social overinvestment $(40.75 \%)$. The exchange of troubled social overinvestment relationships shows that employees judged their leaders very well. Leaders still underestimate the exchange of relations with employees. This condition forms the pride of employees towards leaders.

Leadership is an effort to influence followers' activities through a communication process to achieve specific goals (Donelly, Gibson and Ivancefich, 1995). The evaluation of an organization cannot be separated from the interaction between leaders and employees. Leadership is a process not only applied once in achieving organizational goals. Leadership is a developing relationship where leaders continually generate motivation for employees and modify their behavior to achieve common goals (Yukl, 1994). A leader is expected to be able to identify various situational factors and select leadership models that are combined with organizational characteristics. One influential factor on the leadership effectiveness is the relationship between leaders and employees (Yukl, 1998).

The findings show that Path-Goal approach had more influence on the Vertical Dyad Linkage than the "Hersey and Blanchard" leadership style. The results illustrate that Path-Goal leadership style is more in line with employee's personality traits and work culture of PHCs (Widiantari, Ningsih and Wasnury, 2015). The results show that most of PHC directors applied supportive leadership style. They tend to have friendly interpersonal relationships with employees in order to improve employee performance which would ultimately improve organizational performance.

"Hersey and Blanchard" leadership style was assessed based on task behavior, relationship behavior and employee's maturity levels. The relationship behavior can affect the relationship quality between leaders and employees
(Dansereau, Graen and Haga, 1975). The results also show that "Hersey and Blanchard" leadership style influenced Vertical Dyad Linkage. Participative leadership style influences the Positive Neutral Dyad Linkage category. Participative leadership style is characterized by low directive and high supportive behavior (leaders and employees communicate and work more often) based on the Vertical Dyad Linkage. It suggests that leaders should increase the frequency of their cooperation with employees so that they can be more benefited from the exchanging relationship between the two. The collaborative effort is carried out so that there is an increase of relationship quality between leaders and employees, from positive neutral to positive balance. The results of the study are suitable with what Vertical Dyad Linkage theory states (Graen and Cashman, 1975).

\section{Leadership Style and Vertical Dyad Linkage}

Leadership is an interpersonal influence carried out in certain circumstances, directed at the process of communication to achieve one particular goal or more (Tannenbaum, Massarik and Weschler, 1961). Leadership also emphasizes the influence (authority) on employees. The level of closeness between the leaders and employees shows an indication of leader-member exchange in the company. There are different relationships between leaders and employees in an organization.

Leadership is an effort to influence followers' activities through a communication process to achieve certain goals (Donelly, Gibson and Ivancefich, 1995). An organization cannot be separated from the interaction between its leaders and its employees. Leaders continually generate motivation for employees and modify their behavior to achieve common goals with a particular leadership style applied (Burns, 1978 in Yukl, 1994).

The results show that leadership style based on the Path-Goal approach influences the relationship between leaders and employees. The leadership style based on Path-Goal is more in line with the work culture and personality of employees in a PHC (Widiantari, Ningsih and Wasnury, 2015). Exchanging relationships with high-quality employees (in groups) will invest more time in work and right attitudes of working. Subordinates can carry out tasks that are not in the structure, volunteer to do additional work, and show willingness to take on additional responsibilities (Graen and Cashman, 1975)

The adoption of a supportive leadership style can shape the quality of imbalance social overinvestment relationship exchange (employees are proud of their leaders, but leaders assess that the quality of their relationships is low). Achievement-oriented leadership style will form positive balance relationship, which the quality of the relationship exchange between leaders and employees is excellent because both of them feel the benefits of the relationship. The supportive leadership style illustrates that both leaders and employees will try to show the best performance in order to maintain their relationship (Berger and Meng, 2014). 
The analysis explains that Path-Goal-based leadership styles significantly influence $(58.2 \%)$ the Vertical Dyad Linkage in the PHCs in terms of management aspect, while the rest $(41.8 \%)$ is influenced by other factors that were not examined. Participative leadership style has a significant influence, amounting to 1.4 times greater than directive, supportive, and achievement-oriented leadership styles on the Vertical Dyad Linkage. The score is in the positively neutral category. For participatory leadership style, there has been a proper assessment between the leaders and employees in assessing the quality of the relationship exchange. This value is not too high, so it is grouped into positive balanced category. The relationship between the leaders and employees must be improved in terms of frequency of cooperation to be positively balanced.

Each leadership style will be appropriate and effective since it depends on the situation. Various conditions can influence the context of the questions. Leadership effectiveness depends on the leaders, employees, relationship between leaders and employees, organization, and decision-making time. Leadership effectiveness approach based on "Hersey and Blanchard" is based on mutual influences. The mutual influences include the amount of guidance and direction (task behavior) given by the leaders; socio-emotional support (relationship behavior) shown by the leaders; and the level of readiness displayed by employees in completing a specific task to carry out specific functions or achieve specific goals.

To decide on which leadership style to utilize, the leaders must determine the specific outcome, objectives, sub-tasks, and other tasks that will be completed by the employees. Without this clarity, the leaders will find it difficult to determine the level of employee's maturity and leadership style that suits to the employee's maturity.

Moreover, findings show that the level of employees' maturity cannot be separated from the level of employees' education. The higher the education is, the higher the maturity level will be. These results are in line with the theory of leadership style based on "Hersey and Blanchard" (Hersey and Blanchard, 2004). According to Soeprihanto (2012), formal education will provide opportunities for better achievement. According to Rachmat (2004), one of the situational and influential factors that can influence behavior is the intelligence factor obtained through education. Relationship behavior can affect the quality of relationship between the leaders and the employees (Dansereau, Graen and Haga, 1975).

Based on the results, the "Hersey and Blanchard" leadership style influences the Vertical Dyad Linkage. Participative leadership style influences the Vertical Dyad Linkage in the positive neutral category. Participative leadership style is characterized by low directive and high supportive behavior (leaders and employees often communicate more and work together by exchanging ideas) in accordance with the Vertical Dyad Linkage. The collaborative effort is carried out so that the increasing quality of the relationship between leaders and employees can shift from positive neutral to positive balance. The results of the study are in line with the Vertical Dyad Linkage theory (Graen and Cashman, 1975).

The LMX theory suggests that leaders treat employees differently so that they form "in-group" and "out-group" employees. Similar to Graen's and Chashman's opinion on the LMX-VDL approach, the level of analysis is not appropriate on the working group, but Vertical Dyad Linkage is. Thus, group relationships are needed (Schriesheim, Neider, and Scandura, 1998).

The low level of employees' maturity also affects the Vertical Dyad Linkage in the imbalance formal overinvestment. The high level of employees' maturity affects the imbalance social overinvestment, and very high level of employees' maturity influences the neutral positive category.

\section{Vertical Dyad Linkage and the Performance of PHC}

The description of the relationship between leaders and employees in PHCs in Surabaya can be seen in Figure 1. Figure 1 shows the interpretation of Leader-Member Exchange (LMX) according to the perspective of the leaders and the employees. The results of these measurements are divided into five different LMX qualities. The $x$-axis is the assessment of leader-member exchange conducted by the PHC directors. The $y$-axis is the assessment of leader-member exchange conducted by the employees. The range of $x$-axis and $y$-axis values is obtained from the answers of LMX-MDM questionnaires.

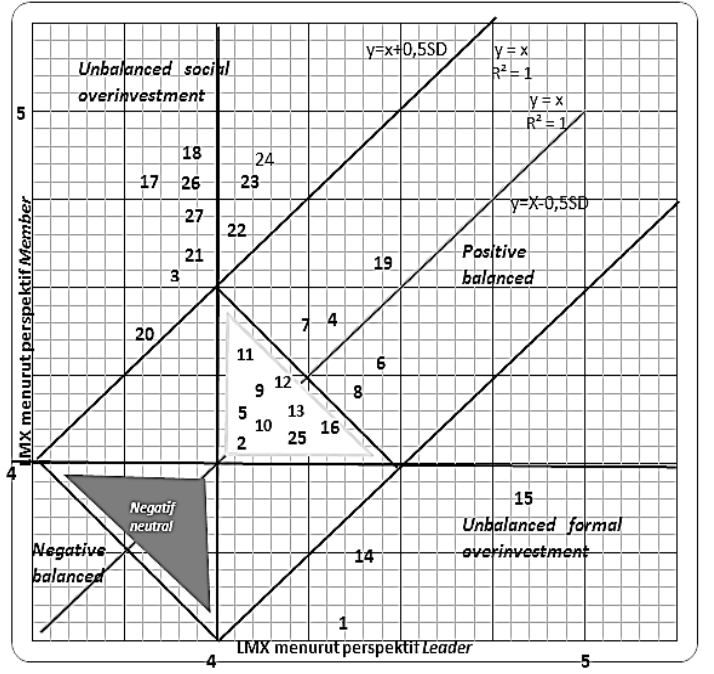

Figure 1. Interpretation Diagram of Leader-Member Exchange (LMX) between Leaders and Employees in the PHC of Surabaya in 2015

There are five different areas in this graph. Each of these areas represents the leader-member exchange between the leaders and the employees. The findings show that four areas describe the relationship between the leaders and the employees. They are imbalanced formal overinvestment, imbalanced social overinvestment, positive neutral, and positive balanced.

The exchange of relationships between leaders and employees can be divided into two, namely in-group relationship or high exchange 
quality and out-group relationships or low exchange quality. Liden, Wayne, and Stiwel (1993) explain that low quality relationships between leaders and employees will reduce employees' performance. The out-group relationship or low LMX involves a limited exchange of relationships on work contracts. Out-group groups carry out routine tasks and experience a more formal exchange of relationships with superiors (Lee, 2000).

Achievement-oriented leadership style is more related to the positive balance of Vertical Dyad Linkage. The effect of Vertical Dyad Linkage on the performance of PHCs, specifically on the management aspect, can be seen in Table 3. Based on Table 3, it is known that the better the quality of the relationship is (positive neutral and positive balance), the better the performance of PHC will be-in the management aspect. The results of the study are contradictory if the relationship between leaders and bad employees results in unbalanced formal overinvestment. The results of the study are in line with the previous research stating that Vertical Dyad Linkage will affect organizational performance (Tariq et al., 2014).

Vertical Dyad Linkage has a significant effect of $63.6 \%$ on the managerial performance of PHCs. There are other factors, amounting to $36.4 \%$, that were not examined. Vertical Dyad Linkage in the positive neutral category results in adequate performance amounted to 285 times greater than the Vertical Dyad Linkage in the unbalanced formal overinvestment, unbalanced social overinvestment, and positive balanced category. The results indicate that the leaders still have an imbalance relationship with their employees.

Table 3. Cross Tabulation of Management Aspect between Vertical Dyad Linkage and the Performance of PHC in 2015.

\begin{tabular}{|c|c|c|c|c|c|c|c|c|}
\hline \multirow{3}{*}{ Vertical Dyad Linkage } & \multicolumn{6}{|c|}{$\begin{array}{c}\text { Performance of PHCs in Terms of } \\
\text { Management Aspect }\end{array}$} & \multirow{2}{*}{\multicolumn{2}{|c|}{ Total }} \\
\hline & \multicolumn{2}{|c|}{ Inadequate } & \multicolumn{2}{|c|}{ Adequate } & \multicolumn{2}{|c|}{ Good } & & \\
\hline & $\mathbf{N}$ & $\%$ & $\mathbf{n}$ & $\%$ & $\mathbf{n}$ & $\%$ & $\mathbf{n}$ & $\%$ \\
\hline Imbalance formal overinvestment & 2 & 100.00 & 0 & 0.00 & 0 & 0.00 & 2 & 100.00 \\
\hline Imbalance social overinvestment & 0 & 0.00 & 9 & 81.80 & 2 & 18.20 & 11 & 100.00 \\
\hline Positive neutral & 0 & 0.00 & 6 & 66.70 & 3 & 33.30 & 9 & 100.00 \\
\hline Positive balance & 0 & 0.00 & 1 & 20.00 & 4 & 80.00 & 5 & 100.00 \\
\hline Total & 2 & 7.40 & 16 & 59.26 & 9 & 33.34 & 27 & 100.00 \\
\hline
\end{tabular}

The level of relationship exchange assessed by the leaders is lower than that assessed by the employees. In this case, the employees provide a higher effort to get closer to their leaders, but this situation is in contrast with the response of the leaders. It means that low mutual relationship between the two influences the exchange of relations between employees and leaders.

\section{CONCLUSION}

The age of directors of PHC is mostly $\geq 50$ years. They are mostly doctors. The level of education plays a role in leadership. Most of the directors have worked for $\geq 18$ years. Most of them are female. The most dominant leadership style applied in PHCs in Surabaya is a supportive leadership style. Most of the leadership styles are based on "Hersey and Blanchard." Other PHCs apply participative leadership style. The employees' maturity level is high. The category of the exchange of relations between leaders and majority of employees is imbalanced social overinvestment. It means that there is an imbalance in the exchange of the relationship (the employees valued their leaders very well, but the leaders evaluated their employees lower). Most of the management aspect in the PHCs in Surabaya have adequate performance.

Path-Goal leadership style influences Vertical Dyad Linkage. Leaders applying the achievement-oriented leadership style will be able to form a neutral Vertical Dyad Linkage. The Vertical Dyad Linkage also affects the performance of PHCs. The better the exchange of relations between the leaders and their employees is, the better the management performance of $\mathrm{PHC}$ will be. The level of employees' maturity influences the Path-Goal leadership style, the management performance of PHCs, and Vertical Dyad Linkage.

PHCs in Surabaya need to conduct leadership training for their directors, such as the Advanced Leadership Skill Training. It is also suggested that the directors of these PHCs should improve management performance in their PHCs. Leadership style based on Path-Goal is more suitable to be applied in PHCs because this leadership style is the most influential factor on the performance of PHCs. The directors of PHCs communicate more with their employees to give pride to their employees so that they can improve the quality of their relationships.

\section{CONFLICT OF INTEREST}

The authors declare that they have no conflict of interests.

\section{REFERENCES}

Berger, B. K. and Meng, J. (2014) Public Relations Leaders as Sensemakers-A Global Study of Leadership in Public Relations and Communication Management. 1st edn. New York: Routledge

Dansereau, F. J., Graen, G. and Haga, W. J. (1975) 'A Vertical Dyad Linkage Approach to Leadership Within Formal Organizations A Vertical Dyad Linkage Approach to Leadership within Formal Organizations A Longitudinal Investigation of the Role Making 
Process', Organizational Behavior and Human Performance, 13. doi: 10.1016/00305073(75)90005-7

Decoster, D. and Fertakis, J. (1968) 'BudgetInduced Pressure and Its Relationship to Supervisory Behavior', Journal of Accounting Research, 6(2).

East Java Province Health Office (2012) Pedoman Penilaian Kinerja Puskesmas di Jawa Timur. Surabaya: East Java Province Health Office.

Erwati, M. (2009) Pengaruh Partisipasi Penyusunan Anggaran Berbasis Kinerja Terhadap Kinerja Kepala SKPD. Jurnal Akuntansi, 102(34).

Donelly, J. H., Gibson, J. L. and Ivancefich, J. M. (1995) Fundamentals of Management. Chicago: Irwin.

Graen, G., \& Cashman, J. (1975). A role making model of leadership in formal organizations: A developmental approach. In J. G. Hunt, \& L. L. Larson (Eds.), Leadership frontiers. Kent, Ohio: Kent State Uni versity Press.

Hastono, S. P. (2016) Analisis Data pada Bidang Kesehatan. Depok: Rajawali Pers.

Hersey, P. and Blanchard, K. (2004) Manajemen Perilaku Organisasi: Pendayagunaan Sumber Daya Manusia. 4th edn. Jakarta: Erlangga.

Indvik, J. (1988) 'A more complete testing of pathgoal theory', in Academy of Management. Anaheim.

Iskandar, M., Ahmad, R., \& Martua, R. H. (2013). Factors Influencing Employees' Performance: A Study on the Islamic Banks in Indonesia. International Journal of Business and Social Science, 5 (2)

Jerald Greenberg, R. A. B. (2003) Behavior in Organizations: Understanding and Managing the Human Side of Work. 8th edn. New Jersey: Prentice Hall.

Ministry of Health of the Republic Indonesia (2014) Peraturan Menteri Kesehatan Republik Indonesia Nomor 75 Tahun 2014 Tentang Pusat Kesehatan Masyarakat. Indonesia.

Kimmel, D. C. (1990) Adulthood and Aging: an Interdisciplinary, Developmental View. 3rd edn. New Jersey: Wiley.

Lee, H.-R. (2000) An Empirical Study of Organizational Justice as a Mediator in the Relationships among Leader-Member Exchange and Job Satisfaction, Organizational Commitment, and Turnover intentions in the Lodging Industry. Dissertation. Virginia Polytechnic Institute and State University. Available at: https://vtechworks.lib.vt.edu/bitstream/handle /10919/27465/dissertation.pdf?se.

Liden, Robert C. Wayne, Sandy J. and Stiwel, Dean. (1993) 'A Longitudinal Study on The Early Development of Leader-Member Exchanges', Journal of Applied Psychology, 78(4), p. 662-674. Available at: https://www.researchgate.net/profile/Robert Liden/publication/232424122 A Longitudinal _Study_on_the_Early_Development_of_Lea der-

Member_Exchanges/links/543e7c890cf21c8 $4 \mathrm{f} 23 \mathrm{~b} 0148 / \mathrm{A}$-Longitudinal-Study-on-the-
Early-Development-of-Leader-Member-

Exchanges.pdf

Liden, Robert C and Maslyn, J. M. (1998) 'Multidimensionafity of Leader Member Exchange: An Empirical Assessment through Scale Development', Journal of Management, 24(1), pp. 43-72. Available at: https://www.researchgate.net/profile/Robert Liden/publication/254121103_Multidimension afity_of_Leader-

Member Exchange An Empirical Assessm ent through_Scale_Development/links/543e 7cad0cf2eaec07e64468/Multidimensionafityof-Leader-Member-Exchange-An-Empiric.

Mardanov, I. Sterrett, J. and Baker, Julie (2007) 'Satisfaction with Supervision and Member Job Satisfaction in Leader-Member Exchange: An Empirical Study in the Restaurant Industry', Journal of Applied Management and Entrepreneurship, 12(3). Available at: https://www.questia.com/library/journal/1P3$1320608991 /$ satisfaction-with-supervisionand-member-job-satisfaction.

Nawawi, H. (2005) Manajemen Sumber Daya Manusia untuk Bisnis yang Kompetitif. 6th edn. Yogyakarta: Gadjah Mada University Press.

Putri, Nuzulul K. and Nurul R., Thini. (2012) 'Pengaruh Gaya Kepemimpinan dan LeaderMember Exchange terhadap Kinerja Unit, Studi Kasus di Rumah Sakit Muhammadiyah Gresik', Jurnal Administrasi dan Kebijakan Kesehatan, 10(1), pp. 18-23. Available at: http://journal.unair.ac.id/downloadfull/AKK69 28-19b67d9c8ffullabstract.pdf.

Popovich, M. G. (1998) Creating High-Performance Government Organizations. 1st edn. New Jersey: Wiley: Jossey-Bass.

Reardon, T. (1998) 'Rural Non-Farm Income in Developing Countries', in The State of Food and Agriculture. Rome: Food and Agriculture Organization.

Schriesheim, C., Neider, L. L. and Scandura, T. A. (1998) 'Delegation and Leader-Member Exchange: Main Effects, Moderators, and Measurement Issues', Academy of Management Journal, 41(3), pp. 298-318. Available at: https://www.jstor.org/stable/pdf/256909.pdf?r efreqid=excelsior\%3A2a3a268b11bc7db4ad $6106 \mathrm{ce} 9977 \mathrm{f693}$.

Soeprihanto, J. (2012) Penilaian Kinerja dan Pengembangan Karyawan. Yogyakarta: BPFE Yogyakarta.

Soesanto, D. (2016) Analisis Pengaruh Gaya Kepemimpinan, Tingkat Maturitas Karyawan, Vertical Dyad Linkage Terhadap Kinerja Puskesmas Kota Surabaya. Thesis. Universitas Airlangga. Available at: http://repository.unair.ac.id/29161/1/HALAM AN DEPAN.pdf.

Sparrowe, R. T. and Liden, R. C. (1997) 'Process and Structure in Leader-Member Exchange', The Academy of Management Review, 22(2), pp. 522-552. Available at: https://www.jstor.org/stable/259332?seq=1\# 
metadata info tab contents.

Tannenbaum, R., Massarik, F. and Weschler, I. R. (1961) Leadership and Organization. A behavioral science approach. New York: McGraw-Hill.

Tariq, Usman. et al. (2014) 'Impact of Leader Member Exchange on Organizational Performance and Commitment with Organizational Culture as Moderator: A NonMonetary Tactic to Enhance Outcome', International Journal of Scientific and Engineering Research, 5(12), pp. 92-100. Available at: https://www.ijser.org/researchpaper/Impactof-Leader-Member-Exchange-onOrganizational-Performance.pdf.

Thoha, M. (2003) Perilaku Organisasi: Konsep Dasar dan Aplikasinya Bibliografi. Jakarta: PT Raja grafindo Persada.

Unaam, A. O., Adim, C. V. and Adubasim, I. E. (2010) 'Employee Loyalty and Organizational Citizenship Behaviour in the Port Harcourt Area Command of the Nigeria Police Force', International Journal of Business, Economics and Management, 5(6). doi: 10.18488/journal.62.2018.56.135.145

Widiantari, Ningsih, D. s. and Wasnury, R. (2015) 'Pengaruh Kepemimpinan dan Lingkungan Kerja Terhadap Semangat Kerja Pegawai Puskesmas Sidomulyo Pekanbaru', Jom FEKON, 2(1), pp. 1-15.

Yoshioka, R. (2006) An Empirical Test Of The Situational Leadership Model In Japan. Thesis. The University Of Texas At Arlington.

Yukl, G. A. (1994) Kepemimpinan dalam Organisasi. Jakarta: Prenhallindo.

Yukl, G. A. (1998) Leadership in Organizations. 5th edn. New Jersey: Prentice Hall. 